\title{
The role of the gut microflora in the utilization of dietary urea by the chick
}

\author{
By J. OKUMURA, D. HEWITT, D. N. SALTER AND M. E. COATES \\ National Institute for Research in Dairying, \\ Shinfield, Reading $R G 2{ }_{9} A T$
}

\section{(Received 4 December 1975 - Accepted 29 fanuary 1976)}

\begin{abstract}
I. In a preliminary experiment, growth of conventional chicks given a basal diet containing adequate amounts of all the essential but none of the non-essential amino acids was improved by supplements of $10.3 \mathrm{~g}$ urea or $50.4 \mathrm{~g}$ glutamic acid/ $\mathrm{kg}$ diet or both.

2. In the main study the effects of supplementing the basal diet with $20.6 \mathrm{~g}$ urea $/ \mathrm{kg}$ were compared in groups of sixteen germ-free and conventional chicks.

3. The germ-free chicks did not benefit from the urea supplement whereas the conventional birds showed improved food conversion efficiency and significantly better growth.

4. In both environments nitrogen retention (( $\mathrm{mg} \mathrm{N}$ intake $-\mathrm{mg} \mathrm{N}$ excreted) $\div \mathrm{g}$ food intake) was higher in the birds given urea, but $\mathrm{N}$ utilization $($ (mg $\mathrm{N}$ intake $-\mathrm{mg} \mathrm{N}$ excreted) $\div \mathrm{mg} \mathrm{N}$ intake) was reduced. This reduction was greater in the germ-free birds.

5. There was a small increase in plasma ammonia concentration in the germ-free birds given urea but a significantly greater increase in the corresponding conventional group.

6. Plasma uric acid concentrations were variable in both groups, and much lower than the normal range. They followed a similar pattern to the plasma ammonia values.

7. More insoluble $\mathrm{N}$ was excreted by the conventional chicks given urea than by the corresponding germ-free group, or by either group given the basal diet.

8. It was concluded that the gut micro-organisms are responsible for the growth-promoting effect of urea, presumably through release of ammonia by bacterial urease $(E C$ 3.5.1.5) and its consequent incorporation into amino acids.
\end{abstract}

In the course of studies on the influence of the gut microflora on protein metabolism in chicks, Salter, Coates \& Hewitt (1974) found that germ-free chicks given a nitrogen-free diet consistently excreted more $\mathrm{N}$ than conventional controls, from which they inferred that $\mathrm{N}$ was being conserved by micro-organisms of the gastrointestinal tract. The lower gut of the chick contains non-protein-N (NPN) in the form of urea, amino acids, ammonia and other products of protein catabolism, some of which are formed by microbial action. According to Salter \& Fulford (1974) endogenous proteins are more likely than dietary proteins to be acted upon by micro-organisms. If the NPN thus formed could be recycled and used by the host a sparing of endogenous $\mathrm{N}$ would be effected. Lee \& Blair (1972) found that conventional chicks can utilize dietary urea as a source of $\mathrm{N}$ for synthesis of amino acids. This capacity might also be mediated through the gut microflora, by bacterial ureolysis and liberation of ammonia which, if absorbed, would provide the necessary $\mathrm{N}$. The importance of micro-organisms in the utilization of NPN by the chick was therefore studied by comparing the nutritional value of urea to germ-free and conventional chicks given diets containing adequate amounts of all the essential but none of the non-essential amino acids. 
Table I. Composition ( $g$ ) of essential amino acid mixture added to the basal diet at $102 \cdot 2 \mathrm{~g} / \mathrm{kg}$

L-arginine $\mathrm{HCl}$
L-histidine $\mathrm{HCl}$ monohydrate
L-lysine $\mathrm{HCl}$
L-tyrosine
L-tryptophan
L-phenylalanine
DL-methionine
L-cystine
L-threonine
L-leucine
L-isoleucine
L-valine
Glycine
L-proline

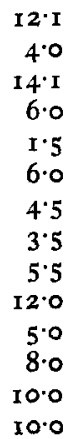

MATERIAL AND METHODS

\section{Chicks}

Germ-free chicks, Rhode Island Red $\times$ Light Sussex, were hatched and reared in Gustafsson stainless-steel isolators as described by Coates, Fuller, Harrison, Lev \& Suffolk (1963). Chicks from the same hatch were reared in a clean but non-sterile environment where the caging, feeding devices and physical conditions were similar to those in the germ-free isolators. They received a practical chick mash for $\mathrm{Iod}$ and were then distributed into the experimental groups. At this stage they were housed in pairs in metabolism cages so that food consumption could be measured and droppings collected quantitatively.

\section{Diets}

The basal diet was essentially the same as that of Lee \& Blair (1972), and was designed to supply the essential amino acids in amounts considered adequate for the growing chick. It contained $(\mathrm{g} / \mathrm{kg})$ : essential amino acid mixture (for details, see Table I) I02.2, maize oil ${ }_{5} 5^{\circ}$, sucrose $216 \cdot 8$, cellulose powder 30 , salt mixture 60 , vitamin triturate $8 \cdot 1$, choline chloride $I \cdot 5$, antacid mixture 10 , maize starch $42 \mathrm{I}^{\circ} 4$. Where necessary, supplements were added at the expense of some of the starch. The salt mixture provided (/kg diet): $\mathrm{CaCO}_{3} \mathrm{I}_{7} \cdot \mathrm{I} \mathrm{g}, \mathrm{KH}_{2} \mathrm{PO}_{4} \mathrm{I} 3.3 \mathrm{~g}, \mathrm{CaHPO}_{4} \cdot 2 \mathrm{H}_{2} \mathrm{O}$ $17 . \mathrm{g}, \mathrm{NaCl} 8.67 \mathrm{~g}, \mathrm{MnSO}_{4} \cdot 4 \mathrm{H}_{2} \mathrm{O} 270 \mathrm{mg} ; \mathrm{KI} 37 \mathrm{mg}, \mathrm{CuSO}_{4} .{ }_{5} \mathrm{H}_{2} \mathrm{O} 16 \mathrm{mg}$, $\mathrm{ZnSO}_{4} \cdot{ }_{7} \mathrm{H}_{2} \mathrm{O}$ I3 $\mathrm{Omg}, \mathrm{MgSO}_{4} \cdot \mathrm{H}_{2} \mathrm{O} 2 \cdot 67 \mathrm{~g}, \mathrm{FeSO}_{4} \cdot 7 \mathrm{H}_{2} \mathrm{O} 670 \mathrm{mg}$. The antacid mixture consisted of equal amounts of $\mathrm{NaHCO}_{3}$ and $\mathrm{Al}(\mathrm{OH})_{3}$. The vitamin triturate supplied (/kg diet): calcium pantothenate $60 \mathrm{mg}$, riboflavin $24 \mathrm{mg}$, thiamin hydrochloride $12 \mathrm{mg}$, pyridoxin hydrochloride $16 \mathrm{mg}$, nicotinic acid $160 \mathrm{mg}$, pteroylmonoglutamic acid $6 \mathrm{mg}$, biotin $800 \mu \mathrm{g}$, cyanocobalamin $80 \mu \mathrm{g}$, retinol (Rovimix 500; Roche Products, Welwyn Garden City, Herts) $20 \mathrm{mg}$. The other fat-soluble vitamins were dissolved in the maize oil to give ( $/ \mathrm{kg}$ diet): cholecalciferol $0.16 \mathrm{mg}$, menaphthone $20 \mathrm{mg}, \alpha$-tocopheryl acetate $40 \mathrm{mg}$. For Expt 2 the diets were sterilized by gammaradiation at 5 Mrad. 


\section{Experimental procedure}

Expt I. This was a preliminary experiment with conventional chicks to test the findings of Lee \& Blair (1972) under the conditions in our laboratory. Four pairs of chicks (one cock and one pullet) were allotted to each of four dietary treatments. They received the basal diet (I) alone, (2) with a supplement of $10.3 \mathrm{~g}$ urea $/ \mathrm{kg}$, (3) with a supplement of $50.4 \mathrm{~g}$ glutamic acid $/ \mathrm{kg}$, or (4) with both urea and glutamic acid supplements, for $8 \mathrm{~d}$. The urea and glutamic acid supplements each provided $4.8 \mathrm{~g} \mathrm{~N}$ (equivalent to $3 \circ \mathrm{g}$ protein) $/ \mathrm{kg}$. The chicks were weighed on alternate days and food consumption was measured. During the last $3 \mathrm{~d}$ droppings were collected in $0.05 \mathrm{M}-\mathrm{H}_{2} \mathrm{SO}_{4}$ and analysed.

Expt 2. This experiment was done using germ-free and conventional chicks, four pairs of cocks and four pairs of pullets to each dietary treatment. They received the basal diet with or without a supplement of $20.6 \mathrm{~g}$ urea $/ \mathrm{kg}$, supplying an amount of NPN equivalent to $60 \mathrm{~g}$ protein. Measurements of body-weight, food consumption and collections of droppings were made as described previously. Blood samples were taken at the end of the $8 \mathrm{~d}$ experimental period, and half were used for determination of plasma ammonia and half were used for determination of plasma uric acid because the volume of blood available from one bird was insufficient to make both determinations.

The following values were calculated:

$$
\begin{aligned}
& \mathrm{N} \text { retention }=(\mathrm{mg} \mathrm{N} \text { intake }-\mathrm{mg} \mathrm{N} \text { excreted }) \div \mathrm{g} \text { food intake, } \\
& \mathrm{N} \text { utilization }=(\mathrm{mg} \mathrm{N} \text { intake }-\mathrm{mg} \mathrm{N} \text { excreted }) \div \mathrm{mg} \mathrm{N} \text { intake, }
\end{aligned}
$$

Food conversion efficiency $(\mathrm{FCE})=\mathrm{g}$ body-weight gain $\div \mathrm{g}$ food intake.

\section{Analytical methods}

Total $N$. The droppings were suspended in saline $(8 \cdot 5 \mathrm{~g} \mathrm{NaCl} / 1)$, homogenized for 5 min using a Silverson homogenizer (Silverson Machines Ltd, London, SE I) and separated by centrifuging at $17000 \mathrm{~g}$, as described by Salter \& Coates (I97 I), into a soluble supernatant fraction (containing dissolved ammonia, urea, amino acids and soluble proteins) and an insoluble residue fraction (containing uric acid, microbial cells and desquamations of the gut mucosa). Total $\mathrm{N}$ was determined in both fractions by a micro-Kjeldahl procedure, using an AutoAnalyzer (Technicon Instruments Co. Ltd, Basingstoke, Hants) to estimate ammonium sulphate formed (Ferrari, 1960).

Collection of blood samples and preparation of plasma. Blood was obtained by cardiac puncture, transferred to heparin-treated centrifuge tubes and immediately centrifuged to separate the plasma.

Plasma ammonia. Ammonia was determined in freshly-prepared plasma by a microdiffusion method as described by Conway (1957).

Plasma uric acid. Uric acid was determined by a uricase ( $E C$ I.7.3.3) method (Morgenstern, Flor, Kaufman \& Klein, 1966) using an AutoAnalyzer. Samples 
Table 2. Expt I. Weight gain, food consumption and nitrogen retention by conventional chicks given a basal diet containing essential amino acids and supplemented with urea $(10.3 \mathrm{~g} / \mathrm{kg})$ or glutamic acid $(50.4 \mathrm{~g} / \mathrm{kg})$ or both

(Mean values for four groups of chicks, one male and one female per group)

\begin{tabular}{|c|c|c|c|c|c|}
\hline & $\begin{array}{l}\text { Wt gain } \\
(\mathrm{g} / \mathrm{d})\end{array}$ & $\begin{array}{l}\text { Food } \\
\text { con- } \\
\text { sumption } \\
(\mathrm{g} / \mathrm{d})\end{array}$ & FCE & $\begin{array}{l}\mathrm{N} \\
\text { retention } t \\
\text { (mg/g food } \\
\text { intake) }\end{array}$ & $\begin{array}{c}\mathrm{N} \\
\text { utilization } \S \\
(\mathrm{mg} / \mathrm{mg} \\
\mathrm{N} \text { intake) }\end{array}$ \\
\hline Period of study (d) $\ldots$ & 8 & 8 & 8 & 3 & 3 \\
\hline $\begin{array}{l}\text { Diets } \\
\begin{aligned} \text { Basal : } & \text { Alone } \\
& + \text { Urea } \\
& + \text { Glutamic acid } \\
& + \text { Urea and glutamic acid }\end{aligned}\end{array}$ & $\begin{array}{l}2 \cdot 64 \\
2 \cdot 85 \dagger \\
3 \cdot 41 \\
4 \cdot 34\end{array}$ & $\begin{array}{l}10.7 \\
10.9 \dagger \\
11.4 \\
12.5\end{array}$ & $\begin{array}{l}0.25 \\
0.26 t \\
0.30 \\
0.35\end{array}$ & $\begin{array}{l}8 \cdot 8 \\
\text { I0.9† } \\
\text { I } 15 \\
\text { I3.3 }\end{array}$ & $\begin{array}{l}0.58 \\
0.5 x+ \\
0.55 \\
0.53\end{array}$ \\
\hline $\begin{array}{l}\text { Effect of dietary supplement } \\
\text { Urea } \\
\text { Glutamic acid } \\
\text { Interaction }\end{array}$ & $\begin{array}{l}0.58^{\mathrm{NB}} \\
\mathrm{I} \cdot 13^{*} \\
0.36^{\mathrm{NS}}\end{array}$ & $\begin{array}{l}0.6^{\mathrm{NS}} \\
\mathrm{I} \cdot \mathrm{I}^{* *} \\
0.4^{\mathrm{NS}}\end{array}$ & $\begin{array}{l}0.03^{\mathrm{Ns}} \\
0.07^{*} \\
0.03^{\mathrm{Ns}}\end{array}$ & $\begin{array}{l}1 \cdot 9^{*} \\
2 \cdot 5^{* *} \\
-0 \cdot 2^{\mathrm{Ng}}\end{array}$ & $\begin{array}{r}-0.04^{\mathrm{NS}} \\
-0.00^{\mathrm{NS}} \\
0.02^{\mathrm{NS}}\end{array}$ \\
\hline SE of effects (I I df) & 0.34 & 0.4 & 0.03 & 0.6 & 0.03 \\
\hline
\end{tabular}

FCE, food conversion efficiency ( $g$ body-wt gain/g food intake); NS, not significant $(P>0.05)$.

* $P \leqslant 0.05$, * $P \leqslant 0.01$.

$\uparrow$ One missing value.

I (mg $N$ intake $-m g ~ N$ excreted $) \div g$ food intake.

$\S(\mathrm{mg} \mathrm{N}$ intake $-\mathrm{mg} \mathrm{N}$ excreted $) \div \mathrm{mg} \mathrm{N}$ intake.

collected from a few birds were too small to allow satisfactory determinations to be made.

\section{Statistical analysis}

With the exception of those for uric acid, the results, in the form of cage values or means, were subjected to analysis of variance. For uric acid, treatment means with their standard errors (based on the variation between individual chicks) are given since there was evidence of heterogeneity of variances between treatments.

In Expt 2 where the sexes were caged separately the males consumed more food than the females $(P<0.05)$ but the interactions between sex, diet and environment were not significant. Differences between the sexes, and interactions involving sex were not significant for all other measurements. The results given in Table 3 are therefore mean values for male and female groups.

\section{RESULTS}

Expt r. Values for weight gains and food consumption for the $8 \mathrm{~d}$ period, and for $\mathrm{N}$ retention and utilization during the last $3 \mathrm{~d}$, are given in Table 2 . The urea supplement, with or without glutamic acid, improved growth but the improvement was not statistically significant. Urea had little or no effect on food consumption or FCE; it significantly increased $\mathrm{N}$ retention but not $\mathrm{N}$ utilization. The supplement of glutamic acid significantly increased weight gain, food consumption and FCE. $\mathrm{N}$ retention was also significantly better but the supplement had no effect on $\mathrm{N}$ utilization. 
(a)

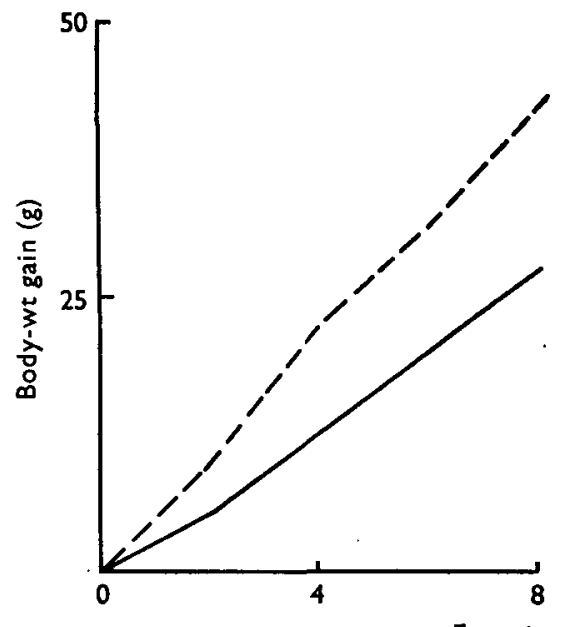

(b)

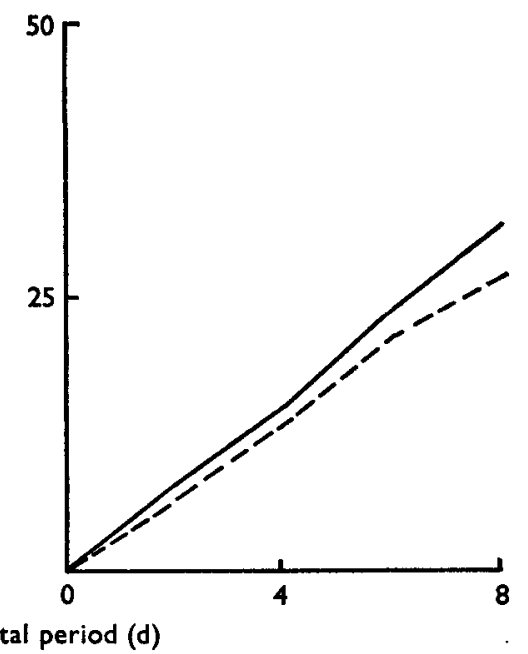

Fig. I. Expt 2. Mean body-weight gains (g) for groups of sixteen conventional (a) and germ-free (b) chicks given a basal diet ( - ) supplying all the essential but none of the nonessential amino acids (for details, see p. 266 and Table I), or the same diet supplemented with $20.6 \mathrm{~g}$ urea $/ \mathrm{kg}(---)$.

Expt 2. Fig. I shows the growth rates in germ-free and conventional environments. Table 3 gives values for weight gains, FCE, plasma ammonia and $\mathrm{N}$ balance. The conventional birds given urea grew significantly better $(P<0.01)$ than the other groups. Urea increased FCE in conventional birds and decreased it in germ-free birds, as evidenced by the significant interaction between diets and environments. Food intake followed the same pattern as the growth rates, being highest in conventional birds given urea. $\mathrm{N}$ retention was increased with the urea-supplemented diet, the effect being much greater in the conventional environment. Although the $\mathrm{N}$ intake was inevitably higher with the urea diet, the proportion retained was less and soluble- $\mathrm{N}$ excretion was significantly increased in both environments. The urea supplement also increased excretion of insoluble $\mathrm{N}$, but to a much greater extent in the conventional birds.

Plasma ammonia concentrations in germ-free and conventional chicks given the unsupplemented diet were very similar. Dietary urea significantly increased plasma ammonia concentration in both environments but the effect was somewhat greater in conventional than in germ-free birds. Plasma uric acid concentrations were also higher with the urea-supplemented diet. The mean values $(\mathrm{mmol} / \mathrm{l})$ with their standard errors were (no. of chicks in parentheses): germ-free: basal (5) $9.5 \pm 2.4$, basal + urea (7) $20 \cdot 2 \pm 4 \cdot 8$; conventional: basal (7) $25 \cdot 6 \pm 7 \cdot 7$, basal + urea (8) $44^{\cdot} \cdot 6 \pm \mathrm{I}^{\prime} \cdot 3$. Further determinations using plasma from groups of seven conventional chicks gave mean values of $67 \cdot 2 \pm 6 \cdot 5$ and $115^{\circ} 4 \pm 16 \cdot 1 \mathrm{mmol}$ uric acid/1 for the unsupplemented and urea-supplemented diets respectively, compared with a value of $368 \cdot 8 \pm 28 \cdot 0 \mathrm{mmol} / 1$ for a group of five chicks reared on a practical chick mash. 
Table 3. Expt 2. Effect of environment, germ-free $(G F)$ v. conventional $(C V)$, and a supplement of $20.6 \mathrm{~g}$ urea/kg diet, on chicks given a basal diet containing essential amino acids but none of the non-essential amino acids

(Mean values for four groups of male and four groups of female chicks, two birds/group. Values for ammonia are based on two groups of each sex)

\begin{tabular}{|c|c|c|c|c|c|}
\hline \multirow[b]{3}{*}{ Dietary treatment } & \multirow{2}{*}{\multicolumn{2}{|c|}{ Environment }} & \multicolumn{2}{|c|}{ Difference $(C V-G F)$} & \multirow[t]{3}{*}{$\mathrm{df}$} \\
\hline & & & & & \\
\hline & GF & CV & Mean & $(\mathrm{CV}-\mathrm{GF}) \dagger$ & \\
\hline \multicolumn{6}{|c|}{$W t$ gain $(g / d)$} \\
\hline $\begin{aligned} \text { Basal : } & \text { Alone } \\
& + \text { Urea } \\
& \text { Difference }\end{aligned}$ & $\begin{array}{c}4.05 \\
3.52 \\
-0.5^{\mathrm{NS}}\end{array}$ & $\begin{array}{l}3 \cdot 65 \\
5.49 \\
\mathbf{I} \cdot 84^{* * *}\end{array}$ & $\begin{array}{c}-0.40^{\mathrm{Ns}} \\
1 \cdot 97^{* * *} \\
2 \cdot 37^{* *}\end{array}$ & $\begin{array}{l}0.50 \\
0.50 \\
0.70\end{array}$ & 24 \\
\hline \multicolumn{6}{|c|}{ Food consumption $(\mathrm{g} / \mathrm{d})$} \\
\hline $\begin{aligned} \text { Basal: } & \text { Alone } \\
& + \text { Urea } \\
& \text { Difference }\end{aligned}$ & $\begin{array}{l}12 \cdot 8 \\
12 \cdot 6 \\
-0.2^{\mathrm{NS}}\end{array}$ & $\begin{array}{l}12 \cdot 7 \\
16 \cdot 5 \\
3 \cdot 8 * * *\end{array}$ & $\begin{array}{c}-0.0^{\mathrm{NS}} \\
3.9^{* * * *} \\
4.0^{* *}\end{array}$ & $\begin{array}{l}0.9 \\
0.9 \\
1 \cdot 3\end{array}$ & 24 \\
\hline \multicolumn{6}{|c|}{ FCE } \\
\hline $\begin{aligned} \text { Basal: } & \text { Alone } \\
& + \text { Urea } \\
& \text { Difference }\end{aligned}$ & $\begin{array}{c}0.32 \\
0.27 \\
-0.04^{\mathrm{Ng}}\end{array}$ & $\begin{array}{l}0.29 \\
0.33 \\
0.05^{\mathrm{NS}}\end{array}$ & $\begin{array}{c}-0.03^{\mathrm{NS}} \\
0.06^{*} \\
0.09^{*}\end{array}$ & $\begin{array}{l}0.03 \\
0.03 \\
0.04\end{array}$ & 24 \\
\hline \multicolumn{6}{|c|}{ Nitrogen retention $\ddagger$ (mg/g food intake) } \\
\hline $\begin{aligned} \text { Basal : } & \text { Alone } \\
& + \text { Urea } \\
& \text { Difference }\end{aligned}$ & $\begin{array}{l}10 \cdot 0 \\
13.3 \\
3.3 * * *\end{array}$ & $\begin{array}{l}\text { I0.4§ } \\
\text { I } 5.9 \\
5.5 * * *\end{array}$ & $\begin{array}{l}0.4^{\mathrm{N} 8} \\
2 \cdot 6^{* * * *} \\
2 \cdot 2^{*}\end{array}$ & $\begin{array}{l}0.4 \\
0.4 \\
0.6\end{array}$ & 23 \\
\hline \multicolumn{6}{|c|}{$\mathrm{N}$ utilization $\|(\mathrm{mg} / \mathrm{mg} \mathrm{N}$ intake $)$} \\
\hline $\begin{aligned} \text { Basal: } & \text { Alone } \\
& + \text { Urea } \\
& \text { Difference }\end{aligned}$ & $\begin{array}{c}0.66 \\
0.54 \\
-0.12 * * *\end{array}$ & $\begin{array}{c}0.68 \S \\
0.64 \\
-0.04\end{array}$ & $\begin{array}{l}0.03^{\mathrm{NS}} \\
0.10^{* * *} \\
0.08^{* *}\end{array}$ & $\begin{array}{l}0.02 \\
0.02 \\
0.03\end{array}$ & 23 \\
\hline \multicolumn{6}{|c|}{$\mathrm{N}$ in soluble fraction $T$ of excreta $(\mathrm{mg} / \mathrm{d})$} \\
\hline $\begin{aligned} \text { Basal: } & \text { Alone } \\
& + \text { Urea } \\
& \text { Difference }\end{aligned}$ & $\begin{array}{r}49 \cdot 3 \\
122 \cdot 7 \\
73 \cdot 3 * * *\end{array}$ & $\begin{array}{l}41 \cdot 8 \S \\
123 \cdot 0 \\
8 I \cdot 2 * * *\end{array}$ & $\begin{array}{r}-7 \cdot 5^{\mathrm{NS}} \\
0 \cdot 3^{\mathrm{NS}} \\
7 \cdot 8^{\mathrm{NS}}\end{array}$ & $\begin{array}{l}7 \cdot 2 \\
6 \cdot 9 \\
9 \cdot 9\end{array}$ & 23 \\
\hline \multicolumn{6}{|c|}{$\mathrm{N}$ in insoluble fraction $\mathrm{f}$ excreta $(\mathrm{mg} / \mathrm{d})$} \\
\hline $\begin{aligned} \text { Basal: } & \text { Alone } \\
& + \text { Urea } \\
& \text { Difference }\end{aligned}$ & $\begin{array}{l}2 I \cdot I \\
3 I \cdot 4 \\
10 \cdot 3^{*}\end{array}$ & $\begin{array}{l}21 \cdot 8 \S \\
46 \cdot 3 \\
24 \cdot 4^{* * *}\end{array}$ & $\begin{array}{l}0.8^{\mathrm{Ng}} \\
14.9^{* * *} \\
\mathrm{I} 4.1 *\end{array}$ & $\begin{array}{l}4 \cdot 0 \\
3 \cdot 9 \\
5 \cdot 6\end{array}$ & 23 \\
\hline \multicolumn{6}{|c|}{ Plasma ammonia $(\mu \mathrm{mol} / \mathrm{l})$} \\
\hline $\begin{aligned} \text { Basal: } & \text { Alone } \\
& + \text { Urea } \\
& \text { Difference }\end{aligned}$ & $\begin{array}{l}\text { I } 16 \\
\text { I } 52 \\
36 *\end{array}$ & $\begin{array}{l}124 \\
201 \\
77^{* *}\end{array}$ & $\begin{array}{r}8 \cdot 2^{\mathrm{NS}} \\
4^{8 \cdot 8^{*} *} \\
40 \cdot 6^{\mathrm{NB}}\end{array}$ & $\begin{array}{l}12 \cdot 9 \\
12 \cdot 9 \\
18 \cdot 2\end{array}$ & 8 \\
\hline \multicolumn{6}{|c|}{ 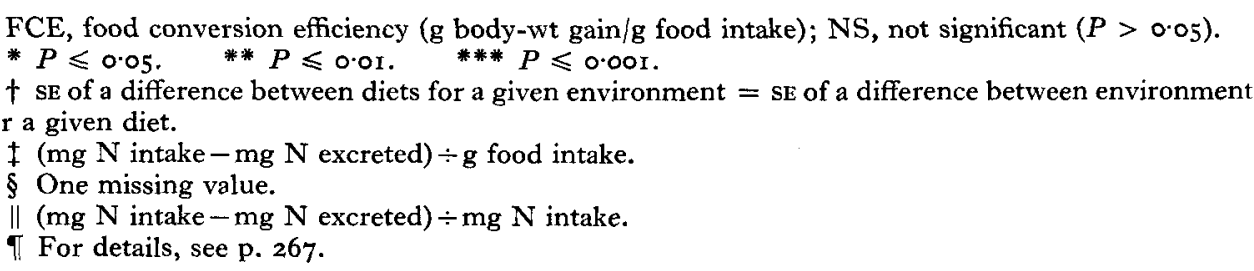 } \\
\hline
\end{tabular}




\section{DISCUSSION}

The results of the preliminary experiment (Expt $\mathrm{I}$ ) were consistent with the findings of Lee \& Blair (1972) and earlier workers (reviewed by Lee \& Blair (1972)) that dietary urea produces a growth response in conventional chicks given a diet devoid of the non-essential amino acids. The response obtained with a supplement of $10.3 \mathrm{~g}$ urea $/ \mathrm{kg}$ diet was not statistically significant nor as great as that produced with a supplement of $50.4 \mathrm{~g}$ glutamic acid/ $\mathrm{kg}$ diet. For this reason the rate of urea supplementation was doubled in Expt 2 . It has been assumed that ammonia released from urea provides the $\mathrm{N}$ source for synthesis of glutamic acid, which the chick is able to form by incorporation of ammonia into $\alpha$-oxoglutaric acid (Lee, McNab, Shannon \& Blair, 1972). It was not known, however, whether the release of ammonia from urea was effected by the gut microflora or by the chick.

The results of Expt 2 establish clearly that the gut micro-organisms are responsible for the growth-promoting effect of urea. The germ-free chicks did not benefit from the supplement, either in weight gain or FCE, whereas the corresponding conventional birds had improved FCE and significantly better growth. In both environments more $\mathrm{N}$ was retained by the birds given urea but $\mathrm{N}$ utilization was reduced. The reduction was much more marked in the germ-free birds, a finding compatible with the failure of urea to elicit a growth response in the germ-free environment.

The marked increase in concentration of ammonia in the plasma of the conventional chicks given urea is consistent with the possibility that ammonia is absorbed after release by bacterial urease $(E C$ 3.5.I.5) in the gut. The smaller but nonetheless significant increase in ammonia in the plasma from germ-free chicks was somewhat unexpected since urease is unlikely to be present in the digestive tract devoid of micro-organisms, and analysis of the irradiated diet indicated that it contained no ammonium ions. Although the main end-product of $\mathrm{N}$ excretion in the bird is uric acid, the urea cycle has a minor role. It seems possible that urea absorbed unchanged from the gut exerted a 'feedback' mechanism on the urea cycle, thus blocking the utilization of ammonium ions for synthesis of glutamate and glutamine. As would be expected, the excess ammonia was apparently excreted as uric acid since the plasma concentrations of uric acid, though not significantly different between themselves, followed a similar pattern to the plasma ammonia values. The uric acid concentrations were considerably lower than the normal range so, to exclude the possibility of an analytical error, further measurements were made on small groups of conventional chicks given either of the two test diets or a practical chick mash. The urea-supplemented diet again produced a higher concentration of plasma uric acid than did the basal diet. Both values were very much lower than those of the birds given the practical chick mash, from which it may be inferred that the essential amino acid mixture supplied in the test diets was efficiently utilized by the birds; the values for $\mathrm{N}$ utilization given in Table 3 are consistent with this inference. Although the amounts of soluble $\mathrm{N}$ excreted by the urea-supplemented birds were much the same in both environments, considerably more insoluble $\mathrm{N}$ was excreted 
by the conventional chicks. Presumably this is accounted for by the incorporation of greater amounts of ammonia into uric acid and into microbial cells.

These experiments were done with birds given a dietary supplement of urea but it seems fair to assume that endogenous urea, or indeed any nitrogenous compound capable of liberating ammonia under microbial action, could be similarly utilized. Thus under conditions of inadequate protein intake the gut micro-organisms may be important in reducing endogenous $\mathrm{N}$ loss.

\section{REFERENCES}

Coates, M. E., Fuller, R., Harrison, G. F., Lev, M. \& Suffolk, S. F. (1963). Br. F. Nutr. 17, I41.

Conway, E. J. (1957). Microdiffusion Analysis and Volumetric Error, 4th ed., p. 120. London: Crosby Lockwood \& Son Ltd.

Ferrari, A. (1960). Ann. N.Y. Acad. Sci. 87, 792.

Lee, D. J. W. \& Blair, R. (1972). Br. Poult. Sci. 13, 243.

Lee, D. J. W., McNab, J. M., Shannon, D. W. F. \& Blair, R. (1972). Br. Poult. Sci. 13, 229.

Morgenstern, S., Flor, R. V., Kaufman, J. H. \& Klein, B. (1966). Clin. Chem. 12, 748.

Salter, D. N. \& Coates, M. E. (1971). Br. F. Nutr. 26, 55.

Salter, D. N. \& Fulford, R. J. (1974). Br. F. Nutr. 32, 625.

Salter, D. N., Coates, M. E. \& Hewitt, D. (1974). Br. J. Nutr. 3r, 307. 